\title{
Non-replication of neurophysiological predictors of non-response to rTMS in depression and neurophysiological data-sharing proposal
}

Citation for published version (APA):

Krepel, N., Sack, A. T., Kenemans, J. L., Fitzgerald, P. B., Drinkenburg, W. H., \& Arns, M. (2018). Nonreplication of neurophysiological predictors of non-response to rTMS in depression and neurophysiological data-sharing proposal. Brain stimulation, 11(3), 639-641. https://doi.org/10.1016/j.brs.2018.01.032

Document status and date:

Published: 13/02/2018

DOI:

10.1016/j.brs.2018.01.032

Document Version:

Publisher's PDF, also known as Version of record

Document license:

Taverne

Please check the document version of this publication:

- A submitted manuscript is the version of the article upon submission and before peer-review. There can be important differences between the submitted version and the official published version of record.

People interested in the research are advised to contact the author for the final version of the publication, or visit the DOI to the publisher's website.

- The final author version and the galley proof are versions of the publication after peer review.

- The final published version features the final layout of the paper including the volume, issue and page numbers.

Link to publication

\footnotetext{
General rights rights.

- You may freely distribute the URL identifying the publication in the public portal. please follow below link for the End User Agreement:

www.umlib.nl/taverne-license

Take down policy

If you believe that this document breaches copyright please contact us at:

repository@maastrichtuniversity.nl

providing details and we will investigate your claim.
}

Copyright and moral rights for the publications made accessible in the public portal are retained by the authors and/or other copyright owners and it is a condition of accessing publications that users recognise and abide by the legal requirements associated with these

- Users may download and print one copy of any publication from the public portal for the purpose of private study or research.

- You may not further distribute the material or use it for any profit-making activity or commercial gain

If the publication is distributed under the terms of Article 25fa of the Dutch Copyright Act, indicated by the "Taverne" license above, 


\section{Non-replication of neurophysiological predictors of non-response to rTMS in depression and neurophysiological data-sharing proposal}

\section{Dear Editor,}

The application of repetitive transcranial magnetic stimulation (rTMS) as a treatment for Major Depressive Disorder (MDD) has been shown to be effective when applied to either the right or left dorsolateral prefrontal cortex (DLPFC) in placebo controlled studies [1,2] as well as open-label studies [3]. Given the effectiveness of rTMS as a treatment for MDD, the interest for finding clinical or (neuro)physiological predictors has been increasing. In 2012, we [4] reported neurophysiological predictors of non-response (NR) for rTMS treatment in MDD. These predictors included the EEG metrics: increased fronto-central theta, a low individual alpha peak frequency (iAPF), and a large P300 amplitude at site location $\mathrm{Pz}$ in a sample of 90 MDD patients, however these biomarkers still require replication. The aim of the current study is to investigate the replicability of these findings in a newly collected sample, and also to make our EEG and ERP data available to scientific use for replication analyses that have specific formulated hypotheses, and thus facilitating future replication studies.

\section{Methods and materials}

\section{Design}

This study was an open-label study (details published recently in this journal [3]. In summary, data for this replication cohort were collected in two clinics (Brainclinics Treatment/neuroCare Nijmegen and The Hague, The Netherlands) between November 2009 and March 2016. Only data from patients with 1) a primary diagnosis of Depression or Dysthymic disorder according to the MINI (MINI Plus Dutch version 5.0.0) and 2) a Becks Depression Inventory (BDI) score of 14 or higher who were treated with left DLPFC HF rTMS $(10 \mathrm{~Hz})$ or right DLPFC LF rTMS $(1 \mathrm{~Hz})$ were included for this study. Exclusion criteria were: previously treated with ECT, epilepsy, wearing a cardiac pacemaker, metal parts in the head and pregnancy. All patients signed an informed consent form before treatment was initiated. Response was defined by achieving response $(>50 \%$ decrease on $\mathrm{BDI})$ or remission $(\mathrm{BDI} \leq 12)$, like in the earlier study. EEG and ERP acquisition and analysis were identical to the methods used in the earlier 2012 study.

\section{Analysis}

Given the confirmatory nature of this data analysis where we specifically aimed to replicate earlier reported measures, we initially only ran One-Way ANOVA's to test differences between responders and non-responders in iAPF, P300 amplitude, and frontocentral theta (for exact processing details see Ref. [4].

\section{Results}

A total of 106 patients were included in this study (average age: 43.92 yrs, range $18-78$ years; 50 females and 56 males; 63 responders). No differences between responders (R) and nonresponders (NR) were found for age, gender, or rTMS protocol (each $\mathrm{p}>$.236). BDI baseline scores were significantly lower for responders than for non-responders $(\mathrm{p}=.018, \mathrm{~F}=5.761, \mathrm{DF}=1)$.

\section{EEG biomarkers}

No significant differences were found between $\mathrm{R}$ and NR for frontal theta (F7, F3, F4; Fig. 1a); P300 amplitude at electrode site $\mathrm{Fz}$ and $\mathrm{Pz}$ (Fig. 1b), nor for iAPF (Fig. 1c). The patterns of results were in the same direction as the original study for P300 and iAPF albeit not significant and with small effect sizes.

\section{Exploratory analysis}

Additional analyses were performed to test for subgroup interactions. One-Way ANOVA's for males and females separately also yielded no significant differences between responders and nonresponders for fronto-central theta, P300 amplitude at Pz, and iAPF. We also performed a univariate analysis with age as a covariate, but this too did not yield significant differences between responders and non-responders on the targeted variables.

\section{Discussion}

The aim of the current study was to replicate the findings from our earlier study [4], however, we were unable to replicate the earlier obtained findings for fronto-central theta, P300 amplitude and iAPF: Numerically the trends and direction of the results were the same for iAPF and P300, however non-significant and with small effect sizes. The results for theta are in line with rather opposite findings throughout the literature where sometimes increased frontal midline theta - with a putative generator in the rostral anterior cingulate cortex - versus decreased frontocentral theta has been found to be related to antidepressant treatment response including rTMS (also see Refs. [5,6] for reviews and data). In a previous paper combining our earlier sample and this 
Figure 1a. ANOVA outcomes for frontal theta, iAPF, and P300.

\begin{tabular}{llllll}
\hline & Responder & Non-responder & $\boldsymbol{F}$ & $\boldsymbol{p}$ & Cohen's d \\
\hline $\begin{array}{l}\text { Theta per } \\
\text { electrode site }\end{array}$ & & & & & \\
F7 & $.7941(.25923)$ & $.7641(.28731)$ & .305 & .582 & .110 \\
F3 & $1.0795(.27429)$ & $1.0310(.28521)$ & .753 & .388 & .173 \\
F4 & $1.0749(.27767)$ & $1.0550(.30055)$ & .120 & .730 & .069 \\
& & & & & \\
P300 amplitude & & & & & \\
Frontal & $7.414(7.333)$ & $5.106(6.911)$ & 2.315 & .132 & .324 \\
Parietal & $11.824(7.964)$ & $11.969(7.087)$ & .008 & .929 & .019 \\
iAPF & & & & & \\
Frontal & $9.048(1.227)$ & $8.891(1.048)$ & .449 & .504 & .138 \\
Parietal & $9.522(1.337)$ & $9.597(.960)$ & .094 & .760 & .064 \\
\hline
\end{tabular}

Figure 1b. P300 amplitude at $\mathrm{Pz}$.

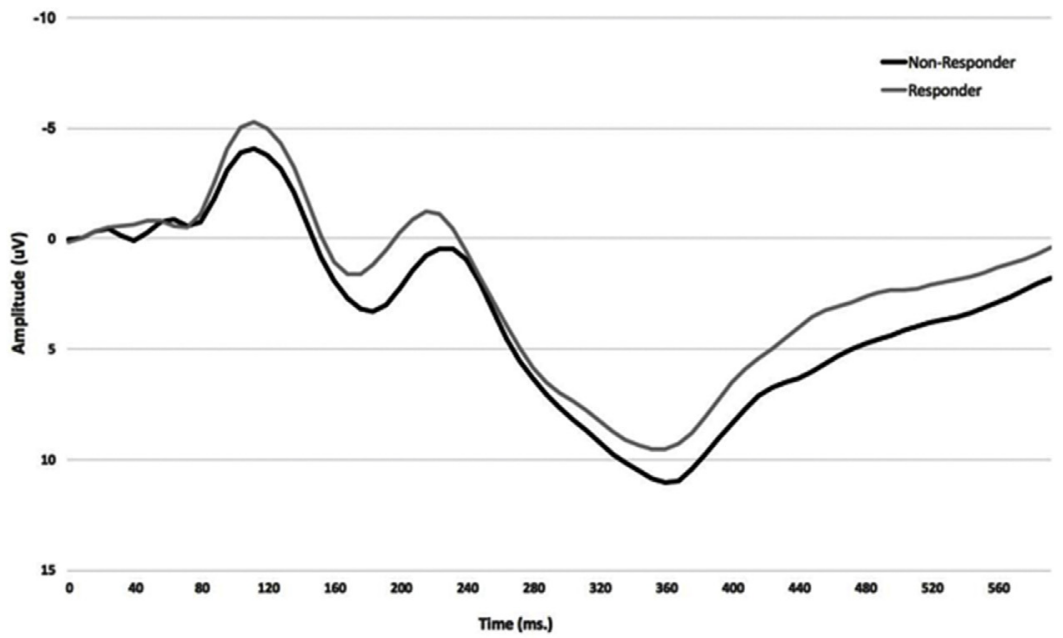

Figure 1c. Power spectrum of iAPF at $\mathrm{F} 3, \mathrm{Fz}, \mathrm{F} 4$, and $\mathrm{Pz}$.
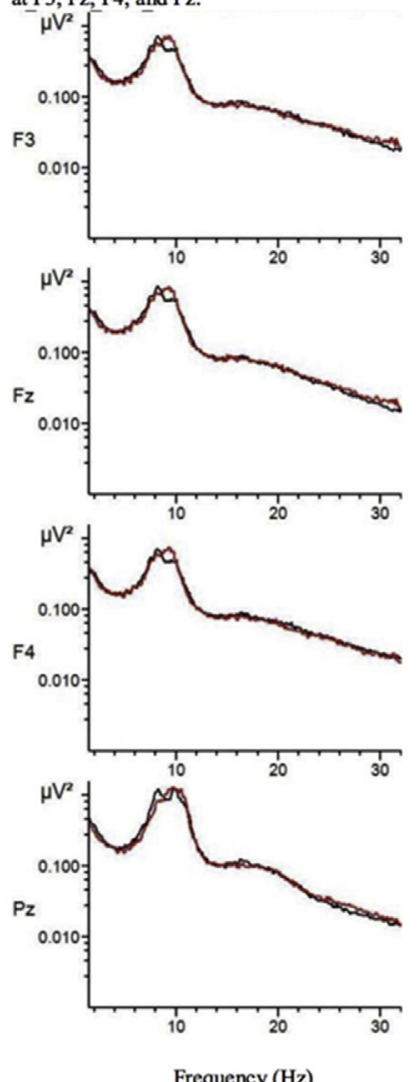

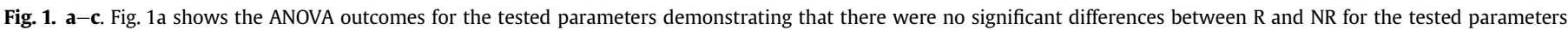

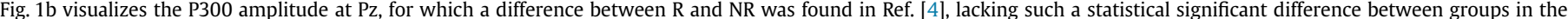

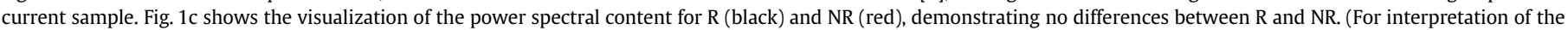
references to colour in this figure legend, the reader is referred to the web version of this article.)

new sample we were unable to find meaningful clinical predictors for treatment response to rTMS treatment in MDD, the predictors including depression severity (rated with BDI), comorbid depression, anxiety and stress (using DASS scales) [3] as well as personality traits (NEO FFI; unpublished findings). These findings demonstrate that future treatment prediction studies should be adequately powered with sample sizes preferably larger than 100 , and furthermore should aim to include replication analyses in order to more reliably report on biomarkers for treatment response. For our future EEG biomarker studies, we have implemented this by a priori dividing our current database into a discovery and replication dataset, which enables us to prospectively verify findings found in the discovery dataset. In addition, to reduce the likelihood of future non-replication, we hereby offer our full sample of EEG and ERP data $(N=196)$ for scientific use in replication analyses employing specifically formulated hypotheses.

\section{References}

[1] Schutter DJLG. Quantitative review of the efficacy of slow-frequency magnetic brain stimulation in major depressive disorder. Psychol Med 2010, Jan 27;40(11):1789-95.

[2] Schutter DJLG. Antidepressant efficacy of high-frequency transcranial magnetic stimulation over the left dorsolateral prefrontal cortex in double-blind shamcontrolled designs: a meta-analysis. Psychol Med 2009, Jan;39(1):65-75.

[3] Donse L, Padberg F, Sack A, Rush AJ, Arns M. Simultaneous rtms and psychotherapy in major depressive disorder: clinical outcomes and predictors from a large naturalistic study. Brain Stimul 2017. https://doi.org/10.1016/ j.brs.2017.11.004.

[4] Arns M, Drinkenburg WH, Fitzgerald P, Kenemans L. Neurophysiological predictors of non-response to rtms in depression. Brain Stimul 2012, Oct;5(4): 569-76.

[5] Pizzagalli DA. Frontocingulate dysfunction in depression: toward biomarkers of treatment response. Neuropsychopharmacology 2011;36(1):183-206.

[6] Arns M, Etkin A, Hegerl U, Williams LM, DeBattista C, Palmer DM, et al. Frontal and rostral anterior cingulate (racc) theta EEG in depression: implications for treatment outcome? Eur Neuropsychopharmacol 2015, Apr 20;25:1190-200.

Noralie Krepel ${ }^{*}$

Dept. of Cognitive Neuroscience, Faculty of Psychology and Neuroscience, Maastricht University, Maastricht, The Netherlands

Research Institute Brainclinics, Nijmegen, The Netherlands

Alexander T. Sack

Dept. of Cognitive Neuroscience, Faculty of Psychology and Neuroscience, Maastricht University, Maastricht, The Netherlands

J. Leon Kenemans Dept. of Experimental Psychology, Utrecht University, Utrecht, The Netherlands

Paul B. Fitzgerald Epworth Healthcare and Monash Alfred Psychiatry Research Centre, Central Clinical School, Monash University, Camberwell, Vic, Australia

Wilhelmus H. Drinkenburg 
Janssen Research \& Development, Beerse, Belgium

Martijn Arns

Research Institute Brainclinics, Nijmegen, The Netherlands

Dept. of Experimental Psychology, Utrecht University, Utrecht, The Netherlands

neuroCare Group Netherlands, Nijmegen, The Netherlands
* Corresponding author. Research Institute Brainclinics, Bijleveldsingel 32, 6524 AD Nijmegen, The Netherlands. E-mail address: noralie@brainclinics.com (N. Krepel).

10 January 2018 Available online 2 February 2018 